\title{
The Forms of Custom Offense (Sanctions) of Waropen Tribe of Papua
}

\author{
Daniel Tanati \\ Senior Lecturer at Faculty of Law, University of Cenderawasih, Papua
}

\begin{abstract}
The losses resulting from the customary offense are not only concerning the material, but also immaterial loss. This clearly shows that customary criminal law is underpinned by a philosophy of harmony and 'communal morality'. The firmly-rooted public trust, that in the case of customs offenses which resulted in an immaterial loss, have implications on a concrete action of the recovery effort in the form of the implementation of certain rituals. In the view of Waropen indigenous tribes, the settlement of a formal judicial custom, through the mechanism of 'criminal proceedings' has not completely resolved the problem. However, in the domain of law enforcement, the role and contribution of customary law cannot be ignored that law enforcement is harmonization of the values of human behavior to implement the ideas or values in the form of law of 'in concreto' requires judges as law enforcement and justice to explore, follow and understand the legal values that live in the community.
\end{abstract}

Keywords: Offense Sanctions; Waropen Tribe.

DOI: $10.7176 / J L P G / 83-12$

Publication date:March $31^{\text {st }} 2019$

\section{Introduction}

Indigenous peoples are estimated to be more than 370 million people and live in more than 70 countries in the world, in various parts of the region. Of this number, there are around 5,000 different groups of indigenous peoples in the world having different cultures on the face of the earth. The indigenous peoples represent more than 4000 different languages from 6700 languages that exist on the face of the earth today. This means that most cultural heritage (language, art, science, etc.) is owned by the indigenous peoples. They are heirs of diversity and at the same time the wealth of civilization and they are not other groups that are so homogeneous (one kind or so similar or even the same in language, behavior, likes, character, art, culture, etc.). ${ }^{1}$

In the context of the Constitution, customary law is legitimized in the United Nation (UN) charter and the constitutions of several countries, namely (1) the Rio 1992 Declaration and 1992 of Agenda 21 which essentially emphasizes the need for recognition and empowerment of the indigenous peoples, where the indigenous peoples are expected to receive fair treatment; (2 ) Draft the United Nations Text on the Rights of the Indigenous Peoples (UN document No.E / CN.4 / Sub.2 / 1992/29) which reinforces the need for alignments with the indigenous peoples which have been neglected; (3) Resolution of 18th General assembly of World Conservation Union, $I U C N$, which unanimously supports the rights of the indigenous peoples including to use local natural resources wisely according to their traditions; and (4) the United Nations Declaration and Program of Action to Combat Racism and Racial Discrimination (UN Declaration and Program of Action) to counter racism and racial discrimination) held in Geneva in which article 21 recognizes the right of the indigenous peoples to preserve the structure of economists traditional and their culture, including language, and special relationships with land and natural resources that should not be taken away from them. ${ }^{2}$

There are various opinions regarding the number of ethnic groups in Indonesia. On the basis of existing language (regional) standards, Esser, Berg or St. Takdir Alisjahbana estimates that there are 200 to 250 ethnic groups in Indonesia. ${ }^{3}$ MS Jaspan has compiled already a temporary list of Indonesian tribes that reached 360 tribes. ${ }^{4}$ According to Koentjaraningrat furthermore, there are 195 ethnic groups in Indonesia with details that there are 42 ethnic groups in Sumatra, in Java and Madura are 8 ethnic groups, in Bali and Lombok are 3 ethnic groups, in Kalimantan is 25 ethnic groups, in Sulawesi is 27 ethnic groups, in Timor is 24 tribes nation, in the Southwestern Islands are 5 tribes, in Maluku is 9 tribes, in Ternate is 15 tribes and in Irian Jaya is 27 tribes. ${ }^{5}$

Papua, which used to be Irian Jaya, is geographically located at the eastern tip of Indonesia. Papua's name

\footnotetext{
${ }^{1}$ Koroba Sem, 2007, The United Nations Declaration On The Rights Of Indigenous People (Deklarasi Perserikatan Bangsa-Bangsa Tentang Tentang Hak-Hak Asasi Masyarakat Adat), 61 session on the General Meeting of the United Nations, Galangpress, New York, pp. 85-86.

${ }^{2}$ Wayan P. Windia, et.al., 2003, Compilation of Regulation on Adat Village in Bali (Kompilasi Aturan tentang Desa Adat di Bal)i, Udayana Bal)i, Udayana Press, Denpasar, pp. $12-13$.

${ }^{3}$ Ibid.

${ }^{4}$ Ibid.

${ }^{5}$ Ibid.
} 
comes from words in the Malay language, namely 'pua-pua', which means "curly hair". ${ }^{1}$ The island of Papua was dubbed by the sailors of the Portuguese nation with the nickname "Isla de Ora" that is meaning "golden island", and the Spanish sailors gave the name Nova Guinea ${ }^{2}$ which in Spanish Nova means new and Guinea means land or place. The Dutch gave the name Papua with New Guinea (Land of Papua). The island is inhabited \pm 263 ethnic Papuans ${ }^{3}$ originating from the Melanesian race family. ${ }^{4}$ The customary law community in Waropen Regency is part of \pm 263 ethnic groups who inhabit the Land of Papua.

In the context of the indigenous Papuans, the basic philosophy behind the indigenous wisdom of the indigenous people of Papua is to maintain and regulate relations or interactions that promote balance, both the balance between humans and humans, humans and nature, humans and their God. This pattern of interaction is a source of knowledge of indigenous people which then gives birth to values of wisdom that underlie patterns of behaviour that regulate the behaviour of indigenous communities in a particular indigenous group so that they become held, valued and have binding strength within the group.

Special autonomy for the Papua Province is basically a special authority that is recognized and granted to the Province and people of Papua to regulate and take care of themselves within the framework of the Unitary State of the Republic of Indonesia. Special authority means giving greater responsibility for the province and the people of Papua to govern and manage the utilization of natural resources in the province of Papua for the greater prosperity of the people of Papua as part of Indonesia in accordance with the legislation. This authority also means the authority to empower the socio-cultural and economic potential of the Papuan people including providing an adequate role for indigenous Papuans.

Waropen Regency as part of the Papua Province which was formed based on the Law Number 26 of 2002 constitutes the expansion of Yapen Waropen as the parent district. In the consideration section of the Law No. 26 of 2006, it is explained that for the progress of the Papua Province in general and the inspiration that develops in the community. It is deemed necessary to improve the administration of government and to service to the community and the implementation of development in realizing community welfare. In addition, it is also emphasized that the formation of districts could encourage improved services in the fields of government, development and community as well as providing capacity in the utilization of regional potential.

Community life as a place where individuals interact has of course differences and even clashes of interests that can give rise to conflict. To resolve the conflict that arises, they consensus form a law and obey it as a form of their obedience or their loyalty to social solidarity. Social awareness forces them to submit and accept, because in a reciprocal relationship. They always need one another against each other as a manifestation of customary law communities. As one example, ${ }^{5}$ in terms of dispute resolution, Indonesia has its own pattern as revealed by Daniel S. Lev. He stated that the legal culture in Indonesia in the way of conflict resolution has its own characteristics caused by certain values. Compromise and peace are values that have strong support from the community. These values tend to put pressure on personal relationships, communal solidarity and avoidance of disputes. Therefore, the thought of developing conflict and its resolution does not receive sufficient support. Maintaining peace is a commendable endeavour, so that in the face of conflict, it is realized in the form of compromise selection, in soft approach.

The emergence of customary cases in various places lately is an indication that the balance of community relations is disrupted. This means that the atmosphere of community life between fellow members of the community does not run harmoniously, but is filled with conflict situations. Such conditions can threaten the lives of rural communities that are safe, secure and peaceful. The customary cases in various places have tried to be resolved through various ways involving various parties, but the process of resolution has been protracted, some have even reached a dead end.

In the customary law community, disputes have been resolved for a long time in deliberations and consensus through customary institutions such as village justice or customary justice. Usually those who act as judges in the institution are traditional leaders (adat leaders) and ulama. The authority of the judge of the customary court is not merely limited to peace, but also the power to decide disputes in all areas of law that are not divided into criminal, civil, public ${ }^{6}$, and others. In this case, the dispute resolution process is carried out

\footnotetext{
${ }^{1}$ Rainer Scheunemann, 2004, Fajar Breaks in Papua "Life and Work of the Papuan Apostle Johann Gottlob Geissler (1830 - 187 0) and His Legacy for the Present (Fajar Merekah Di Tanah Papua "Hidup Dan Karya Rasul Papua Johann Gottlob Geissler (1830 - 1870 ) dan Warisannya Untuk Masa Kini”), Panitia Jubelium Emas 150 Tahun Hari Pekabaran Injil di Tanah Papua, Jayapura, p. 30.

${ }^{2}$ Alua Agus A, 2002, West Papua From the lap to the lap A chronological overview (Papua Barat Dari Pangkuan Ke Pangkuan Suatu lkhtisar Kronologis), Seri Pendidikan Politik Papua No. 1, Sekretariat Presidium Dewan Papua dan Biro Penelitian STFT Fajar Timur, Jayapura, pp. $4-5$.

${ }^{3}$ Warami, Hugo, 2006, Dou Sandik Guyub Tutur Biak Numfor, Papua, Tesis, Denpasar, p. 1

${ }^{4}$ Anonim, Something concerning Papuan People Council (Tentang Majelis Rakyat Papua), Bakesbang Provinsi Papua, Jayapura, p. 9.

${ }^{5}$ Ade Maman Suherman, 2006, An Introduction of Legal System Comparative (Pengantar Perbandingan Sistem Hukum), PT. RajaGrafindo Persada, Jakarta, p. 16.

6 Hilman Hadikusuma, 1992, An Introduction Indonesian Customary Law (Pengantar Ilmu Hukum Adat Indonesia), Mandar
} 
based on three work principles to deal with customary matters, namely the principles of harmony, worthiness and harmony. ${ }^{1}$

The existence of customary justice or village justice can be an alternative dispute resolution for the community whose work system is more or less similar to the alternative modern dispute resolution that is now developing, where deliberation becomes the general and main model in the dispute resolution process. This means that customary justice institutions do not act as a means of coercion, but play a role as a mediator in the context of reconciliation and consolidation of the parties through the process of finding decisions that relieve all parties, because basically the decisions are taken voluntarily by the parties.

\section{Research methods}

The nature of this research was descriptive research. ${ }^{2}$ The sources of data were library data and field data. The library data was classified from primary, secondary and tertiary legal materials in order to find sources of material relating to legal concepts and rules. The library data applied the snowball method. The field data obtained from in-depth interviews with key informants expected in Waropen district. The data was then analysed qualitatively.

\section{Findings and Discussion}

\subsection{Form of Waropen Tribal Customs Sanctions}

The dispute resolution substance based on local potential is a concrete effort of the parties in dispute to find their own law observed. The efforts to resolve disputes leading to peace have long been recognized by the Indonesian people, even those efforts have institutionalize into what is called village justice (doorpsjustice). In the past, this village judiciary existed throughout the archipelago which is now called Indonesian territory and its authority has been basically both criminal law and civil law. The settlement process is measured by existing dispute resolution practices, so the dispute resolution process is based on local potential, which in the past seemed simple. However, dispute resolution based on local potential is a principle that the law is created, not to be violated. It has to be respected and adhered to achieve peace. At that time, people who violated the law were seen as violating public interests. In the context of village justice as disciplinaire rechtspraak, court of conduct is held not to retaliate, but to build peace.

In its development, the policies of the colonial government began to influence the policies of the village government. As a result, the quality and value of the village court experienced a change, this was seen when in the years 1925 - 1927, an investigation was held about the need to revive the village court of law. At that time the civil service was forced to declare his doubts about the purity of the court's soul. Although there were other scholars who argued that the village court needed to be revived. It must be based on a law which simultaneously regulated criminal, civil, material forms, and the limits of village court authority.

At that time the legal basis underlying the entry into force of the village court was Article 25 in the phrase of Reglemhent which said that if there was a planting dispute between villagers in the field of civil law, family law, and inheritance law. The village head then with the help of the committee adjudicated the dispute by reconciling it. In general, the people who are in disputes agreed with the proposal of the village head. Of course, there were exception in that case of certain people disagreed. For example, if there were people who disagree with the proposal of the village head, the case was brought forward to the district head. This official will once again try to reconcile the disputing parties. When at this stage there was no resolution, the "wedana" (the head of village) was also obliged to advance this case to a court that has the authority to do so as well as provide guidance on the procedures for submitting it.

What the village court did at that time was that the law was interpreted as an educational tool and a court of justice which was placed in the hands of the community members themselves. The court of conduct has a high value in state and society. This condition was responded positively by the colonial government. In fact, the colonial government at that time gave the legal basis as stated in Bijblaad 1246. This was done because the substance of dispute resolution based on local potential through village courts had been born, grew, and developed in various regions. In each region, there are cultural themes which are essentially the same in substance, which is to uphold the culture of deliberation. Substantially, Indonesian culture contains cultural themes that exist in resolving disputes based on local potential. To mention a few of them are "bulek aia dek pambuluah bulek kato dek "deliberation" in Minangkabau society, "glurung tanpa bolo, menang tanpo ngasura" (win-win solution) in the Java community, "harmony jagad gede and jagad cilik" in the local community for dispute resolution based on local potential.

Maju, Bandung, p. 40.

${ }^{1}$ Moh. Koesnoe, 1974 , Some Notes on Customary Law Nowadays (Catatan Terhadap Hukum Adat Dewasa Ini), Erlangga University Press, Surabaya, pp. 44-45.

${ }^{2}$ Amiruddin dan Zainal Askin, 2004, An Introduction to Legal Research Methodology (Pengantar Metode Penelitian Hukum), PT. Raja Grafindo Persada, Jakarta, p. 25. 
Law is a socio-cultural phenomenon that functions to apply certain rules and patterns of behaviour to individuals in society. ${ }^{1}$ Law as a social norm is inseparable from the values that apply in a society and can even be said that the law is a reflection and concretization of values which at one time prevailed in society. ${ }^{2}$ Customary law as "living law" is essentially a pattern of community life, where the law processes and at the same time is the source and basis of the law itself. The customary law growth is directly from its basic foundation, namely the legal awareness of the community. In a religious community, the customary law always grows and develops in line with the community it regulates. In such circumstances, the customary law is inseparable from the elements of religion absorbed as the source and basis of customary law itself.

Indeed there is a strong tendency sociologically that religion has certain functions in social interactions as written by Soerjono Soekanto. ${ }^{3}$ They are:

1.With the belief in the power above humans that are related to the purpose of life and human well-being, the religion provides support and a sense of peace to the lives of human beings and life with them;

2.The religion provides the foundations of peace of life and a stronger identity for humans in life that are sometimes shaky and full of changes;

3.The religion provides a sacred basis for the values and norms that apply in society. The religion can also maintain harmony between individual interests with group interests and maintain group interests;

4.The religion provides fundamental argumentation to assess some norms;

5. The religion provides an assessment of the norms;

6. The religion supports the process of human growth, development and maturation in society.

Every human being has a behaviour, which is a totality and motor movement, perception and cognitive function of humans. One element of behaviour is social motion, which is essentially a system that includes a hierarchy of settings. ${ }^{4}$ Regarding human behaviour, it analytically can be distinguished between mere behaviour and ethical behaviour. ${ }^{5}$

In social behaviour involved in the behaviour of several parties, then a process of mutual influence might also occur. Social interaction between individuals is sometimes referred to as interpersonal relations. The point is that there is a relationship between humans and humans based on certain needs. Interpersonal needs is the need to establish relationships with other people, which if not implemented will result in disturbances or unpleasant conditions for the person concerned. ${ }^{6}$ Although these interpersonal needs produce various behaviours but in principle humans have a desire to live regularly. To achieve this order, a life guide or standard is needed in the association which will provide a forum for various views on order which are originally personal views. These guidelines or standards are commonly called norms or rules .

Norms or rules serving as guidelines for interpersonal relations are distinguished between norms or rules of decency and law. ${ }^{7}$ Legal norms establish patterns of relations between humans and also formulate the values received by society into certain patterns. So that there are clear boundaries about patterns of behaviour that are contrary to the values received by the community concerned. The relations as mentioned before contain meaning on contact reciprocally or inter-stimulation and response of individuals from groups .

In social interactions taking place in this way, there are always 4 (four) possibilities which are forms of social interaction itself, as followings:

1. Co-operation. It means that good relations between individuals in relationships are established. Therefore, everything takes place harmoniously and there are no significant tensions.

2. Competition. It means that between elements in social life, between one power and another have begun to have a feeling of wanting to excel. If this takes place in a healthy manner, certainly there will be no tensions, but if the opposite, it can lead to tension.

3. Conflict. It means that in society there is a conflict between certain social forces and others to cause social tensions.

4. Accommodation or the occurrence of a settlement. It means that tense conditions will subside because they are handled by elements of social life, so that the community will regain order. ${ }^{8}$

\footnotetext{
${ }^{1}$ Soerjono Soekanto, 1983, Law Enforcement (Penegakan Hukum), BinaCipta, Jakarta, p. 54.

2 Ibid. p. 22

${ }^{3}$ Soerjono Soekanto, 1982, Legal Awareness and Legal Order (Kesadaran Hukum dan Kepatuhan Hukum), Rajawali, Jakarta, pp. 155 - 156.

${ }^{4}$ Soerjono Soekanto and Soleman B. Taneko, 1983, Indonesian Customary Law (Hukum Adat Indonesia), Rajawali, Jakarta, pp. 74 - 75.

Talcott Parsons also states that social action is bound by 4 factors, namely first, it is referred to reach a certain aim. Second, it takes place in certain situation. Third, it is regulated in certain norms, and the last, it is pushed by certain motivation.

${ }^{5}$ Purnadi Purbacaraka and Soerjono Soekanto, 1983, Regarding the Legal Norms (Prihal Kaidah Hukum), Alumni, Bandung, pp. 24 - 25.

${ }^{6}$ Ibid, p.76.

${ }^{7}$ J.H.A. Logeman argues that the rule of law is in reality manifested in legal decisions, where the rule of law is manifested in human relations. Likewise, Timacheff writes that generally norms and non-laws will clearly determine human behavior in society. The basis of a law or rule of law is the assumption that there is a relationship between behavior that enters into the form of law with real behavior of individuals. Furthermore, see David M. Scheff., "Law as a Social Phenomenon" in Adam Podgorecki and Christopher J. Whelan (Ed.), 1987, Sociological Approach to Law, Bina Aksara, Jakarta, p. 253.

${ }^{8}$ Soedjono, 1977, The Basic of Sociology of Law as Supporting of Legal Study (Pokok-pokok Sosiologi Hukum Sebagai Penunjang Studi
} 
The four possibilities as mentioned above occur in social interaction and will take place in any community, including communities in villages in Waropen Regency, Papua Province. It means that there is harmony among fellow citizens at one time, in which there is a harmonious reciprocal relationship between individuals. However, at other times, social tensions occur due to the actions of a person or group of people. These tensions will be restored, if the solution has been resolved.

According to customary law, conflicted actions with the rules of customary law are 'illegal' and the customary law recognizes efforts to improve the law (rechtsherstel) if the law is violated. ${ }^{1}$ These conflicted acts are commonly called 'custom delicts'. According to Ter Haar, the custom delict (offense) is:

"every disorders one side category (eenzijdig) on the balance and every crash of the one side category in terms of material and immaterial of the goods of life of a person or many people constitute one unit (group); Such actions create a reaction whose its nature and size are determined by the customary law. It means that, the reaction of adat (adatreactie) should create the balance and it must be restored (mostly the violations are paid in the form of goods or money)". 2

Ter Haar furthermore explain that the word offense is intended to be a one-off act which is not openly justified or secretly directed towards evenwichts verstoring. So in the sense of Ter Haar as indicated above, to be classified as offense, these actions must cause shock in the balance of society. The balance refers both moveable things (tangible) and immovable things (intangible). Bushar Muhammad, on the other hand' gives restrictions on custom delicts as:

"unilateral act created by a person or group of people to threaten or offend or disturb the balance and community life either material or immaterial to the person or to the public in the form of unity. Such actions result in an indigenous reaction". 3

Soepomo further did not express a limitation about customary offenses. He just explains that in the customary law system all actions that conflict with customary law are illegal and the customary law also recognizes efforts to improve the law if the law is violated".

From the description of the boundaries of customary delicts as mentioned by some scholars, the concept of customary offenses used in this paper is actions that violate the sense of justice and order that live in the community resulting in disruption of the peace and balance of the community. To restore peace and balance, a customary reaction is needed.

In principle, the birth of traditional delict according to Soepomo 4 is similar to the birth of each unwritten legal regulation. A regulation concerning human behaviour at a time gets the legal nature when the legal officer concerned defends it against people who violate the regulation, or when the law officer acts to prevent violations of the regulation. Furthermore, it is also explained that the traditional Indonesian mind is 'cosmic' which sees everything as a whole (totality). In this traditional mind, the organization of society is aimed at maintaining the balance between the world of birth and the unseen world, between the whole human group and the individual, between friends of fellowship and society. All actions that interfere with the balance are a violation of the law and legal officers must take action.

The customary delict can arise, develop and then disappear with the emergence of new regulations, while the new regulations will also develop as well, which will then disappear with the change in feelings of justice in society. From time to time, these changes will follow the dynamics of society. Likewise, the customary delict, it births, develop, and then disappear by themselves in the sense that actions which are originally seen as violations that may not be considered as such. All of this goes along with the development of a sense of justice in the community concerned. Even this feeling of justice is essentially developing to follow the development and growth of people's lives which are always influenced by external factors.

In customary law communities (Kampoing) in Waropen regency, there are various acts which are considered as customary violations both heavy or tiny violations. The violation can be seen in four districts, namely Maserei Districts, Urei Faisei District, Waropen Bawah District, and Oadate District. Those violations can be classifies, as followings:

1. Delict against body and soul;

2. Delict against property;

3. Delict against someone's honour;

4. Delict against morality; and

5. More delicts.

However, in each village / district, the mention of the name of the delict is different to the language of each

Hukum), Alumni, Bandung, pp. 93 - 94.

${ }^{1}$ Soepomo, 1983, The Chapters of the Customary law (Bab-bab Tentang Hukum Adat), Pradnya Paramita, Jakarta, p. 60.

2 Ter Haar, 1978, The Principles and The Structure of the Customary Law (Azas-azas dan Susunan Hukum Adat (Beginselen en Stelsel van het Adatrecht)), translated by Kng. Soebakti Poesponoto,, Pradnya Paramita, Jakarta, p. 226.

${ }^{3}$ Bushar Muhammad , 1983, The Basic of the Customary Law (Pokok - Pokok Hukum Adat), Pradnya Paramita, Jakarta, p. 67.

${ }^{4}$ Ibid., pp.111-112. 
region. The following are the names of the delict as classified as customary delicts in each district:

\section{3 .1. 1. Maseirei District}

The Maseirei District consists of 14 villages (kampong) with a population of more than 3,159 people. It is consisting of 8 villages and 6 tribes. The 8 villages means that they have the same regional language and belong to the Waropen Kai ethnic group, while the other 6 tribes are classified as Ronari waropen tribe, namely: ${ }^{1}$

1. Mambai;

2. Fafado;

3. Risei;

4. Wobari;

5. Bokadaro;

6. Fafai;

7. Sinonde;

8. Koweda;

9. Oadate;

10. Aniboi;

11. Mayawahedo;

12. Urate;

13. Sauri Sirami; and

14. Rowiare.

Actions that can be identified as customary delicts, namely:

\begin{tabular}{|c|c|c|c|c|}
\hline No. & Classification & Name / designation in the local language & Sanctions & Information \\
\hline 1 & $\begin{array}{l}\text { Delict to body } \\
\text { and soul }\end{array}$ & $\begin{array}{l}\text { 1. Munio (persecution) } \\
\text { 2. } \quad \text { Famunio (torturing using tools) } \\
\text { 3. Munifero (persecution that results } \\
\text { in death }\end{array}$ & $\begin{array}{c}\text { Fine } \\
\text { Fine } \\
\text { Submitted } \\
\text { to the } \\
\text { police }\end{array}$ & $\begin{array}{l}\text { The size and form of fines } \\
\text { are determined by } \\
\text { traditional institutions, } \\
\text { village heads and security }\end{array}$ \\
\hline 2 & $\begin{array}{l}\text { Delict to } \\
\text { property }\end{array}$ & Humamana (theft) & Fine & $\begin{array}{l}\text { The size and form of fines } \\
\text { are determined by } \\
\text { traditional institutions, } \\
\text { village heads and security }\end{array}$ \\
\hline 3 & $\begin{array}{l}\text { Delict to } \\
\text { someone's } \\
\text { honor }\end{array}$ & $\begin{array}{l}\text { Ghadadumana (harassment for the name of } \\
\text { the village head) }\end{array}$ & Fine & $\begin{array}{l}\text { The size and form of fines } \\
\text { are determined by } \\
\text { traditional institutions, } \\
\text { village heads and security }\end{array}$ \\
\hline 4 & $\begin{array}{l}\text { Delict to } \\
\text { morality }\end{array}$ & $\begin{array}{l}\text { 1. Wererai (divorce husband / wife } \\
\text { without valid reasons) This Delik is } \\
\text { divided into } 2 \text { groups, namely: } \\
\text { a. Ri Bingga : if a husband divorces } \\
\text { his wife without a valid reason. } \\
\text { b. Ri Mango : if the wife divorces } \\
\text { her husband without a valid reason. } \\
\text { 2. Omamana (Zina) }\end{array}$ & Fine & $\begin{array}{l}\text { The size and form of fines } \\
\text { are determined by } \\
\text { traditional institutions, } \\
\text { village heads and security }\end{array}$ \\
\hline 5 & $\begin{array}{l}\text { Other } \\
\text { violations }\end{array}$ & $\begin{array}{l}\text { Yai Iningga (pet / loose breeding cow, then } \\
\text { eating other people's plants so as to cause } \\
\text { harm) }\end{array}$ & Fine & $\begin{array}{l}\text { The size and form of fines } \\
\text { are determined by } \\
\text { traditional institutions, } \\
\text { village heads and security }\end{array}$ \\
\hline
\end{tabular}

3 .1.2 Urei - Faisei District

Urei-faisei District consists of 7 villages with a population of approximately 4,387 people. It consists of tribes, namely:

1. Faisei Saubowoa tribe (Sangei);

2. Nuwoa Tribe (Nubuai);

3. Mambui tribe; and

4. Woyui Tribe (Paradoi).

\footnotetext{
${ }^{1}$ Number of tribes identified. The number of tribes is due to the standard of language used as a guideline.
} 
Actions that can be identified as customary delicts, namely:

\begin{tabular}{|c|c|c|c|c|}
\hline No. & Classification & $\begin{array}{c}\text { Name / designation in the } \\
\text { local language }\end{array}$ & Sanctions & Information \\
\hline 1. & $\begin{array}{l}\text { Delict to body and } \\
\text { soul }\end{array}$ & $\begin{array}{l}\text { Fanio (persecution), also } \\
\text { mentioned in other terms, } \\
\text { such as: Kifanio, Kimunio. }\end{array}$ & $\begin{array}{c}\text { Fine } \\
\text { Plate or money }\end{array}$ & $\begin{array}{l}\text { Fines were imposed by Sera } \\
\text { assisted by Sera Titibi and } \\
\text { Eso }\end{array}$ \\
\hline 2. & Delict to property & $\begin{array}{l}\text { 1. Kimbembanda (theft } \\
\text { committed jointly / } \\
\text { more than one person) } \\
\text { 2. Wumbeanmbda (theft } \\
\text { perpetrators only } 1 \\
\text { vote) }\end{array}$ & Fine & $\begin{array}{l}\text { In the past, if fines were } \\
\text { dropped, it was usually in } \\
\text { the form of the obligation to } \\
\text { hand over the roof / cork }\end{array}$ \\
\hline 3. & $\begin{array}{l}\text { Delict to someone's } \\
\text { honour }\end{array}$ & $\begin{array}{l}\text { There is no term, but the term } \\
\text { for the person who commits } \\
\text { harassment, is called " } \\
\text { Swanggi" and if the } \\
\text { harassment is committed } \\
\text { against women, the } \\
\text { term"Onaruruwaei" }\end{array}$ & Fine & - \\
\hline 4. & Delict to morality & $\begin{array}{l}\text { Minarei (adultery) if it is } \\
\text { done by someone who is not } \\
\text { yet in legal status, the name } \\
\text { isWimabo -Waribo. }\end{array}$ & Married & $\begin{array}{l}\text { If you do not want to get } \\
\text { married, a custom and } \\
\text { money will be imposed by } \\
\text { customary decisions }\end{array}$ \\
\hline 5. & Other delicts & $\begin{array}{l}\text { Raika Rongu: acknowledges } \\
\text { the rights of others }\end{array}$ & Fine & - \\
\hline
\end{tabular}

\section{1. 3. Waropen Bawah District}

The Waropen Bawah District consists of 12 villages with a population of approximately 4. 721 inhabitants. It is consisting of 5 large trains, namely:

1. Sawai Keret;

2. Wairo keret;

3. Saimua Keret;

4. Imbiri Keret; and

5. Watofa Keret.

In the district of Waropen Bawah, there are not many names of customarydelicts / violations, but in languages that have been commonly accepted by villagers in the Waropen Bawah district. There is a term or nigogoko or niyaro which means community members who do not know adat. However, in this study, it can also be identified (names) several types of customary delicts, which if classified include also in criminal acts against the body and soul, criminal acts directed at property, criminal acts against honour, criminal acts against morality and other types of delictss, as shown in the following table:

\begin{tabular}{|c|c|c|c|c|}
\hline No. & Classification & $\begin{array}{c}\text { Name / designation in the local } \\
\text { language }\end{array}$ & Sanctions & Information \\
\hline 1. & $\begin{array}{l}\text { Delict to body } \\
\text { and soul }\end{array}$ & Munggaiwara (persecution) & $\begin{array}{l}\text { Custom sanctions } \\
\text { fine } \\
\text { Plate or money } \\
\end{array}$ & $\begin{array}{l}\text { For people outside } \\
\text { the village, sanctions } \\
\text { can be expelled }\end{array}$ \\
\hline 2. & $\begin{array}{ll}\text { Delik } & \text { to } \\
\text { property }\end{array}$ & $\begin{array}{l}\text { 1. Humamana (theft) } \\
\text { 2. Yokoharo (fraud) }\end{array}$ & $\begin{array}{l}\text { Custom sanctions } \\
\text { fine } \\
\text { Plate or money }\end{array}$ & - \\
\hline 3. & $\begin{array}{l}\text { Delik to } \\
\text { someone's } \\
\text { honor }\end{array}$ & - & - & - \\
\hline 4. & $\begin{array}{ll}\text { Delict } & \text { to } \\
\text { decency }\end{array}$ & $\begin{array}{l}\text { 1. Youmamana (Zina) } \\
\text { 2. Customary violations that prohibit } \\
\text { marriage for those who have close } \\
\text { blood relations }\end{array}$ & $\begin{array}{l}\text { Custom sanctions } \\
\text { fine } \\
\text { Plate or money }\end{array}$ & - \\
\hline 5. & $\begin{array}{l}\text { Other } \\
\text { violations }\end{array}$ & $\begin{array}{l}\text { Nigogoko or Niyaro (a termcommonly } \\
\text { used to indicate that the person does } \\
\text { not know customary rules) }\end{array}$ & fine & - \\
\hline
\end{tabular}

From several types of customary delicts, it can be seen that the types of criminal acts have been regulated in 
the Criminal Code as general criminal offenses. However in the view of the local indigenous people, these types of violations included customary offenses.

Regarding the type of customary violation, the settlement is carried out before the village head and customary head. The decisions taken are all based on consensus meetings, in a traditional ritual called 'Waisowosiyo' which means let's sit together to solve problems. ${ }^{1}$ Moreover, in violation of the custom of "fighting" or persecution, the Waisowosiyo ritual has meaning. In the view of indigenous peoples in the Waropen Bawah district villages, the formal justice process of adat cases only resolves problems on the surface, and has not resolved the problem thoroughly. This ritual is also intended to avoid the existence of revenge that can not only be carried out by the immediate family of the victim, but also possibly by the descendants of the victims.

\section{1. 4. Oadate District.}

Oadate originates "Owa Furu" and "Date". Owa Furu means people who do not know anything / nomads. Whereas "Date" means a group of people on land. Literally, Oadate means the bond of land people. The term land people connotes more on the differentiation of coastal warriors with those who inhabit the plains on the Waropen land. However, it should be noted that in the view of the indigenous people of Oadate, in principle, all people come from the land, then some of them go to the coast. Part of the Oadate Tribe is classified as Waropen Ronari tribe, namely Tribe of Demisa, Tribe of Ghoria / Oa, and Tribe of Saponi / Kuriye.

Oadate District consists of 5 villages with a population of approximately 1984 people. In the Oadate district, there are approximately 18 tribes, but in this study only 4 tribes are represented, namely:

1. Demisa

2. Ghoria / Oa tribe

3. Saponi / Kuriye tribe

4. Nuwoa tribe (West Kai tribe)

Among the Demisa tribal people, the authority of the Adat Council is led by a large tribal customary chief called "Date Teadiya". The chief of the tribe is assisted by the supreme commander in chief, the high adat court and the field war commander. In the Demisa tribe, a provision stipulates that a boy, before marriage, is obliged to study in traditional schools. The traditional schools can be in the past, up to 12 years and then change to 6 years, then change to 3 years, change again to 1 year. Now, the customary school only lasts for 3 months because among the tribes there are fears that this traditional school activity can be suspected of being a violation of the rules. The completion of the person concerned carries out the obligation to study in traditional schools to be a benchmark that a person has grown up ("basire"). For those who have not received customary school education it is called "boose".

The customary schools among Demisa tribes teach various skills such as warfare / attack tactics strategies, and recognising enemies, adaptation to nature / environment to the ability to transform into animals such as rats, crocodiles or Kaswari and also the ability to summon the certain animals. If examined from the explanation above, it can actually be concluded that the customary school is actually closely related to the situation and conditions at that time, where a member of the tribe must be able to maintain his life and life, both defending from the opponent's attacks and how they can survive by having hunting skills by calling on animals that will be the target of their aim.

Among tribes in the Oadate district, terms of customary delicts are not known. It is just generally accepted the term "Kaowamero". It is used as a term for violations of customary norms, both for violations in the form of theft, persecution or murder. In the Oa/Choria, tribe violations of customary norms are called "Birimdate" or "Datefiyae" which means people are not good. In the past, customary violations were always threatened with the death penalty as an absolute verdict from the tribal chief. The chief ("Oa") in exercising his authority is assisted by "Oedate" or "Oweidate" as representatives and also "Kumambe" (war society) and "Oboadamo" (general public). This tribe also knows about customary schools, only different in the period of implementation compared to the Demisa tribe. Traditional schools in the Oa / Choria tribe only lasted 1 year, then changed to 6 months. And after the entry of religion and government, customary schools only last 7 days (1 week). But the same is the material taught in traditional schools, similar to what is taught in the Demisa tribal school. The people who belong to the $\mathrm{Oa} /$ Choria tribe, refer to customary violations as "Dilimdamo" which means wrongful customary rules.

Interestingly, in this study there were found 2 ways of customary peace in the settlement of cases of customary violations, called "Sarohe" or customary banana peace. In this ritual, Sarohe bananas are burned together (among those involved in the conflict). After the bananas were cooked, all took a standing position and the tribal chief began to speak, then followed by a joint oath not to make a conflict. Then, the banana was broken and the rest was distributed to each citizen. Among the Oa / Choria tribes, it is also known as a method of peace

${ }^{1}$ Interviewed with Gharak Rumabin Anthonius. Rumboisano, (The Head of Tribe of Besar Sawai). 
called "Atayumero" (exchange of peace). This settlement pattern is usually carried out on marital cases or fights. The way is by exchanging certain facilities, which in the past are usually in the form of "wemo" (dog), "jubi" (arrow).

\section{Conclusion}

Criminal law (adat) is found in acts which are included as violations of customary norms, which, if classified, include criminal acts against property, bodies and souls, morality, honor of a person. For various types of customary violations found in 4 districts (Maseirei, Urei Faisei, Waropen Bawah and Oadate) actually include general offenses and are regulated in the Criminal Code, but in the view of indigenous people, these types of crimes include customary offenses based on custom of the local community.

\section{Bibliography}

Ade Maman Suherman, 2006, An Introduction of Legal System Comparative (Pengantar Perbandingan Sistem Hukum), PT. RajaGrafindo Persada, Jakarta.

Alua Agus A, 2002, West Papua From the lap to the lap A chronological overview (Papua Barat Dari Pangkuan Ke Pangkuan Suatu lkhtisar Kronologis), Seri Pendidikan Politik Papua No. 1, Sekretariat Presidium Dewan Papua dan Biro Penelitian STFT Fajar Timur, Jayapura.

Amiruddin dan Zainal Askin, 2004, An Introduction to Legal Research Methodology (Pengantar Metode Penelitian Hukum), PT. Raja Grafindo Persada, Jakarta, p. 25.

Anonim, Something concerning Papuan People Council (Tentang MajeIis Rakyat Papua), Bakesbang Provinsi Papua, Jayapura.

Bushar Muhammad , 1983, The Basic of the Customary Law (Pokok - Pokok Hukum Adat), Pradnya Paramita, Jakarta.

David M. Scheff., "Law as a Social Phenomenon" in Adam Podgorecki and Christopher J. Whelan (Ed.), 1987, Sociological Approach to Law, Bina Aksara, Jakarta.

Hilman Hadikusuma, 1992, An Introduction Indonesian Customary Law (Pengantar Ilmu Hukum Adat Indonesia), Mandar Maju, Bandung.

Koroba Sem, 2007, The United Nations Declaration On The Rights Of Indigenous People (Deklarasi Perserikatan Bangsa-Bangsa Tentang Hak-Hak Asasi Masyarakat Adat), 61 session on the General Meeting of the United Nations, Galangpress, New York.

Moh. Koesnoe, 1974 , Some Notes on Customary Law Nowadays (Catatan Terhadap Hukum Adat Dewasa Ini), Erlangga University Press, Surabaya.

Purnadi Purbacaraka and Soerjono Soekanto, 1983, Regarding the Legal Norms (Prihal Kaidah Hukum), Alumni, Bandung.

Rainer Scheunemann, 2004, Fajar Breaks in Papua "Life and Work of the Papuan Apostle Johann Gottlob Geissler (1830 - 187 0) and His Legacy for the Present (Fajar Merekah Di Tanah Papua "Hidup Dan Karya Rasul Papua Johann Gottlob Geissler (1830 - 187 0) dan Warisannya Untuk Masa Kini”), Panitia Jubelium Emas 150 Tahun Hari Pekabaran Injil di Tanah Papua, Jayapura.

Soedjono, 1977, The Basic of Sociology of Law as Supporting of Legal Study (Pokok-pokok Sosiologi Hukum Sebagai Penunjang Studi Hukum), Alumni, Bandung.

Soerjono Soekanto, 1983, Law Enforcement (Penegakan Hukum), BinaCipta, Jakarta. Jakarta. 1982, Legal Awareness and Legal Order (Kesadaran Hukum dan Kepatuhan Hukum), Rajawali,

Soerjono Soekanto and Soleman B. Taneko, 1983, Indonesian Customary Law (Hukum Adat Indonesia), Rajawali, Jakarta.

Soepomo, 1983, The Chapters of the Customary law (Bab-bab Tentang Hukum Adat), Pradnya Paramita, Jakarta.

Ter Haar, 1978, The Principles and The Structure of the Customary Law (Azas-azas dan Susunan Hukum Adat (Beginselen en Stelsel van het Adatrecht)), translated by Kng. Soebakti Poesponoto,, Pradnya Paramita, Jakarta.

Warami, Hugo, 2006, Dou Sandik Guyub Tutur Biak Numfor, Papua, Tesis, Denpasar.

Wayan P. Windia, et.al., 2003, Compilation of Regulation on Adat Village in Bali (Kompilasi Aturan tentang Desa Adat di Bal)i, Udayana Press, Denpasar. 